\title{
Anti-oxidative effects of flavonoids enriched Corni fructus extract and the mechanism
}

\author{
Soo-Hwan Lim, Sung Ho Choi, Yun Im Oh and Sung-Jin Kim*
}

Department of Pharmacology and Toxicology, School of Dentistry, Kyung Hee University, Seoul, Korea 130-701, Korea.

Accepted 4 April, 2011

\begin{abstract}
We tested to determine if Corni fructus extract has antioxidant activities and explored its potential mechanism in terms of iNOS and COX-II involvement. Anti-oxidative actions were explored by measuring free radical (NO, DPPH) scavenging activity, and TBARS levels. The mechanism of antioxidative action of Corni fructus extract was determined by performing Western blot analysis for iNOS and COX-II expression in lipopolysaccharide (LPS) stimulated Raw cells. $70 \%$ methanolic extract of Corni fructus exerted significant DPPH free radical scavenging activity in a dose-dependent manner. The DPPH-free radical scavenging activity was stronger than that of vitamin E. It also markedly inhibited TBARS formation. Strikingly, the Corni fructus extract has dramatic reducing power with maximal activity observed as 231-fold over control. Production of iNOS induced by LPS was significantly inhibited by the Corni fructus extract, suggesting it inhibits NO production by suppressing iNOS expression. However, COX-2 induced by LPS was not significantly altered by the Corni fructus extract. The Corni fructus extract contains anti-oxidant components including phenolics, flavonoids and anthocyanin at the concentration of $18.07,2.31$ and $7.83 \mathrm{mg} / \mathrm{g}$, respectively. The subsequent chloroform fraction enriched with flavonoids almost completely blocked the iNOS induction and NO production caused by LPS in the Raw cells.
\end{abstract}

Key words: Corni fructus, free radical, iNOS, NO, COX-II, lipid peroxidation.

\section{INTRODUCTION}

Corni fructus is the dryed fruit of Cornus officinalis SIEB and Zucc which belongs to the Cornaceae family. These trees grow wild in China and the central and southern part of our country. With a diversity of efficacy and flavor, it has long been used as a medicinal stuff in traditional oriental medicine and folk remedies and is widely used as a material of liquor, tea or herb medicines. It contains cornin that is known to stimulate parasympathetic nerves, glycosides such as morroniside, loganin, tannin and saponin, organic acids such as gallic acid, linolic acid, palmitic acid and ursolic acid, and vitamin A plus a considerable amount of sugar. It also contains 18 kinds of minerals and abundant $\mathrm{K}, \mathrm{Ca}, \mathrm{Mg}$ and amino acid (Ding, 2007). It increases the secretion of acetylcholine, thereby promoting the secretion of insulin (Hsu et al., 2006). A number of reports ave been published regarding its

\footnotetext{
*Corresponding author. E-mail: kimsj@khu.ac.kr
}

pharmacological effects: corniside separated from Corni fructus extracts causes relaxation of the smooth muscles of blood vessels (Kang et al., 2007); Corni fructus extracts has anticancer effects against hepatoma cells or leukemic cells (Chang et al., 2004). In addition, it has been found that polysaccharides in Cornus officinalis modulate immunologic functions (Du et al., 2008), and morroniside had the ability to prevent neurotoxicity caused by oxidative stress (Wang et al., 2009). It has been found that $C$. officinalis (has the ability to enhance cognitive action (Lee et al., 2009) and to inhibit melanogenesis (Nawa et al., 2007). Antioxidants play important roles for us to maintain health and they are mainly ingested through foods such as fruits or vegetables. They serve the roles of suppressing or delaying lipid peroxidation and removing free radicals (active oxygen). Antioxidants such as vitamin C, vitamin E, phenolic acid, flavonoids can reduce the risk of chronic inflammations such as tumors or heart diseases and they are helpful in neutralizing active oxygen which is unstable molecules 
that are involved in the onsets of those diseases (Sanbe et al., 2007). iNOS is a key enzyme responsible for the production of nitric oxide (NO) and it plays an important role in the oxidative stress and inflammation (Conforti and Menichini, 2011; Codener-Franch et al., 2011); it has been suggested that COX-II is also take part in the same processes (Uchida, 2008). In this study, we explored to determine if Corni fructus extracts have anti-oxidative activites and tested whether iNOS, NO and COX II are involved in anti-oxidative actions exerted by Corni fructus extracts.

\section{MATERIALS AND METHODS}

\section{Preparation of plant extracts}

Authentic samples of Corni fructus were purchased from KyungDong Oriental Market in Seoul. They were authenticated by Emeritus Professor Chang-Soo Yok, Department of Oriental Pharmacy, College of Pharmacy, Kyung Hee University, Seoul, KOREA. A voucher specimen (No. 4N-006) was deposited at the Herbarium of the Department of Pharmacology, School of Dentistry, Kyung Hee University. Corni fructus (100 g) was cut into small pieces and extracted with $70 \%$ methanol $(300 \mathrm{ml})$ for $3 \mathrm{~h}$ three times. The resulting methanol extract was concentrated by rotary evaporator and dried by freeze-dryer, yielding approximately $25.7 \mathrm{~g}$. Then $10 \mathrm{~g}$ of freeze-dried $70 \%$ methanol extract was resuspended with $200 \mathrm{ml}$ methanol-water (1:1.5) solution, adjusted to $\mathrm{pH} 3$ with $2 \mathrm{M} \mathrm{H}_{2} \mathrm{SO}_{4}$, further extracted with $200 \mathrm{ml}$ of chloroform (three times). The chloroform fraction was concentrated using the rotary evaporator, and followed by freeze-drying, yielding $0.2 \mathrm{~g}$ (Fraction C).

\section{Reagents and materials}

The iNOS and COX-2 antibodies were bought from Cell Signaling and Santa Cruz Biotechnology Co., respectively. The ECL kit was bought from Amersham Co. Other reagents were bought from Sigma Co. All cell culture media were purchased from Gibco Co.

\section{Free radical scavenging activity}

Free radical scavenging activity was measured by evaluating the ability to remove DPPH under the principle of reduction reactions of DPPH radical solutions in the presence of hydrogen-donating antioxidants (Brand-Williams et al., 1995). Briefly, Corni fructus extract dissolved in $1 \mathrm{ml} \mathrm{MeOH}$ was missed with $1 \mathrm{ml} \mathrm{DPPH}$ solution at $23^{\circ} \mathrm{C}$ and optical density was measured in $30 \mathrm{~min}$ at $515 \mathrm{~nm}$.

\section{Measurement of lipid peroxidation (TBARS measurement)}

The final products of polyunsaturated fatty acid oxidation reaction will react with thiobarbituric acid (TBA) to form red floaters. Thiobarbituric acid reactive substances (TBARS) were measured by the Sroka's method (2003). The TBA reagent was prepared as follows. Reagent A: $375 \mathrm{mg}$ of thiobarbituric acid (Fluka chemical) and $30 \mathrm{mg}$ of tannic acid were melted into $30 \mathrm{ml}$ of hot water. Reagent B: $15 \mathrm{~g}$ of thiobarbituric acid was melted into $70 \mathrm{ml}$ of 0.3 $M$ hydrogen chloride solution. Then, $30 \mathrm{ml}$ of reagent $A$ and $70 \mathrm{ml}$ of reagent B were mixed up. Rapeseed oil $(5.2 \mu \mathrm{l})$ was suspended in $2 \mathrm{ml}$ of $0.2 \mathrm{M}$ Tris-HCL buffer $(\mathrm{pH} 7.4)$ containing $15.6 \mathrm{mg}$ of Tween-40. The produced suspension was irradiated with UV light for $60 \mathrm{~min}$ at $25^{\circ} \mathrm{C}$ and then $100 \mu \mathrm{l}$ of Corni fructus extracts were mixed with $1 \mathrm{ml}$ of the suspension. This mixture was irradiated with UV light for $30 \mathrm{~min} .2 \mathrm{ml}$ of TBA reagent was put into the mixture and then the mixture was made to react for $15 \mathrm{~min}$ in boiling water and centrifuged for $3 \mathrm{~min}$ at $100 \times \mathrm{g}$ and the supernatant fluid was taken and the optical density was measured at $532 \mathrm{~nm}$. The suppression of lipid and oxidation reactions was measured as the percentage to the control group not containing Corni fructus extracts.

\section{Reducing power}

The reducing power of Corni fructus extract was measured using the Oyaizu's (1986) method. $2.5 \mathrm{ml}$ of Corni fructus extract $(0.2 \mathrm{M}$ phosphate buffer, $\mathrm{pH} 6.6$ ) was put into $2.5 \mathrm{ml}$ of potassium ferricyanide $(10 \mathrm{mg} / \mathrm{ml})$ solution and made to react for $15 \mathrm{~min}$ at $30^{\circ} \mathrm{C}$. $2.5 \mathrm{ml}$ of Trichloroacetic acid $(100 \mathrm{mg} / \mathrm{ml})$ was put into the reactant and mixed up and $2.5 \mathrm{ml}$ of the mixture was again mixed with $2.5 \mathrm{ml}$ of distilled water and $0.5 \mathrm{ml}$ of ferric chloride $(1.0 \mathrm{mg} / \mathrm{ml})$ and optical density was measured at $700 \mathrm{~nm}$.

\section{Cell culture}

Murine RAW 264.7 macrophage cells were cultured in Dulbecco's modified Eagle's Medium (Gibco BRL, Grand island, NY) with $10 \%$ heat-inactivated fetal bovine serum in $5 \%$ humidified $\mathrm{CO}_{2}$ atmosphere at $37^{\circ} \mathrm{C}$.

\section{Measurement of nitric oxide (NO)}

Raw cells were cultured with DMEM and 10\% FBS. NO was measured by measuring the amount of $\mathrm{NO}$ in the cell supernatant as nitrite and nitrate. The safe form of nitrite after being reduced to nitrate was measured using the Greiss reagent (Sigma, USA). 2 x $10^{6}$ Raw cells were put into a 6 well plate and washed two times with PBS when the confluence was $80 \%$ and then cultured for at least $24 \mathrm{~h}$ and the samples were made into the final concentrations of $10,1.0$ and $0.1 \mathrm{mg} / \mathrm{ml}$ for experiments. Four hours later, LPS of the final concentration $1 \mathrm{mg} / \mathrm{ml}$ was put into all wells except for the well for the control group to stimulate the samples. The amounts of NO generated were measured by gathering the supernatant around $18 \mathrm{~h}$ later, having them react with the Greiss reagent for $10 \mathrm{~min}$ after shading and then measuring the optical density at $540 \mathrm{~nm}$.

\section{Measurement of iNOS and COX-II expression by Western blotting}

When the cells reached confluence, the DMEM culture medium was removed and replaced by the EMEM culture medium which is a serum-free culture medium and then the cells were treated with Corni fructus extracts and cultured for $24 \mathrm{~h}$. The cells were washed two times with PBS and scraped into a buffer containing $10 \mathrm{mM}$ Tris- $\mathrm{HCl}, \mathrm{pH} 7.4,50 \mathrm{mM} \mathrm{NaCl}, 5 \mathrm{mM}$ EDTA, $30 \mathrm{mM} \mathrm{NaF}, 0.1 \mathrm{mM}$ $\mathrm{Na}_{3} \mathrm{VO}_{4}, 1 \%$ triton $\mathrm{X}-100,0.5 \% \mathrm{NP}-40,1 \mu \mathrm{g} / \mathrm{ml}$ leupetin, $1 \mu \mathrm{g} / \mathrm{ml}$ aprotinin. Then, the cells were disrupted by passing them through a $1 \mathrm{ml}$ tuberculin syringe five times. The cell lyaste was subjected to centrifugation at $10,000 \times \mathrm{g}$ for $10 \mathrm{~min}$ and the supernatant was used for Western blot analysis. The protein content of the soluble fraction was assessed by the method of Bradford (1976). Protein (50 $\mu \mathrm{g} / \mathrm{lane}$ ) was electrophoretically separated in $10 \%$ polyacrylamide gels containing SDS. Proteins were transferred to nitrocellulose membranes was carried out for $1 \mathrm{~h}$ at $100 \mathrm{~V}$ (constant) as described by Towbin et al. (1979). The filter papers were preincubated for $1 \mathrm{~h}$ at $23^{\circ} \mathrm{C}$ with PBS containing $0.1 \%$ Tween 


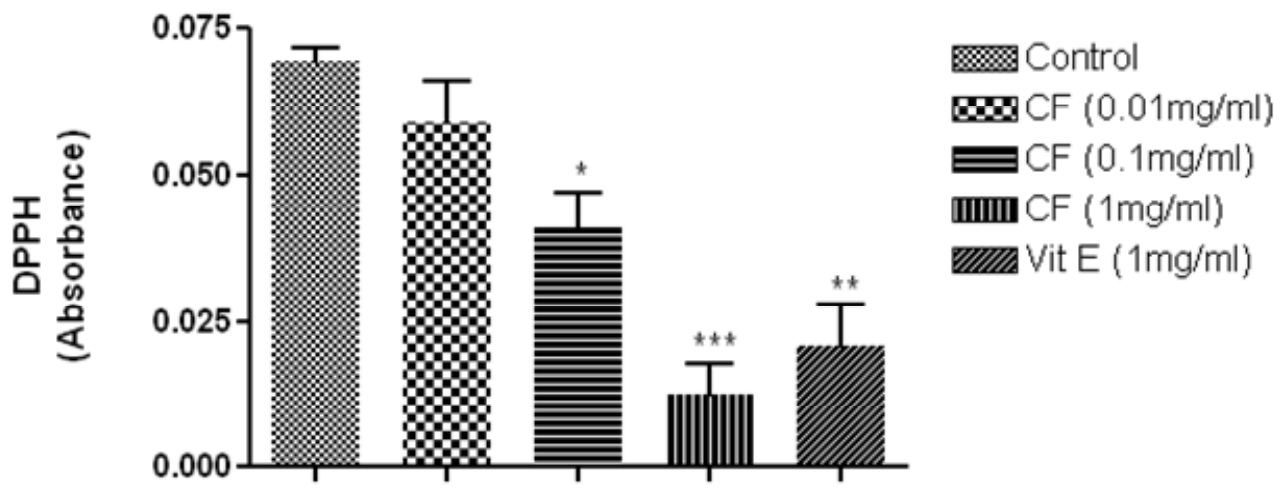

Figure 1. DPPH scavenging activity by Corni fructus extract. DPPH scavenging activity of Corni fructus extracts was measured as described in the Methods. All the measured values were shown as means \pm S.E.M of three experiments and showed significant differences from those of the control group at the levels of $\mathrm{P}<0.05$ and ${ }^{* *} \mathrm{P}<0.01$.

20 and $5 \%$ skim milk and washed with PBS containing $0.1 \%$ Tween 20 three times for 10 min each. Followed by the blots were probed with primary antibody directed against iNOS $(1: 1,000)$, COX-II $(1: 2,000)$, GAPDH $(1: 1000)$ for $2 \mathrm{~h}$ at room temperature or overnight at $4{ }^{\circ} \mathrm{C}$ diluted in blocking buffer. The blots were then incubated with HRP-conjugated anti-rabbit IgG (1:1,000 for iNOS and GAPDH; 1:2,000 for COX-II) for $1 \mathrm{~h}$ at room temperature and washed with PBS containing Tween 20 three times for 10 min each. The detection of immobilized specific antigens was carried out by ECL (NEN). The images analysed using Image $\mathrm{J}$ software.

\section{Component analysis (anthocyanin, phenolics, flavonoids)}

\section{Measurement of total phenolics}

The total phenolics content was measured using the FolinCiocalteau procedure at $725 \mathrm{~nm}$ (Singleton and Rossi, 1965). Gallic acid was used as a standard for phenolic compounds and the phenolic concentration was calculated by using a gallic acid standard calibration curve. The total phenolics content was expressed as the gallic acid equivalent (mg gallic acid/ $\mathrm{g}$ extract).

\section{Measurement of total flavonoids}

The total flavonoids existing was measured using the method of Miliauskasa et al. (2004) and was expressed as the rutin eqivalent ( $\mathrm{mg}$ rutin acid/ $\mathrm{g}$ extract) using rutin as a standard flavonoid. $1 \mathrm{ml}$ of Corni fructus extracts was mixed with aluminum thichloride in ethanol $(20 \mathrm{mg} / \mathrm{ml})$ and diluted to $25 \mathrm{ml}$. After incubation for $40 \mathrm{~min}$ at $20^{\circ} \mathrm{C}$, the optical density was measured at $415 \mathrm{~nm}$.

\section{Measurement of total anthocyanin}

The total anthocyanin was measured using color reactions (Piccolella et al., 2008). Corni fructus extracts were dissolved in 1 $\mathrm{ml}$ of acetate buffer $(25 \mathrm{mM}, \mathrm{pH} 4.5)$ and the optical density was measured at $520 \mathrm{~nm}$. The content of anthocyanin was expresssed as kouromanin equivalent (mg kouromanin / $\mathrm{g}$ extract).

\section{Statistical analysis}

All data were expressed as mean \pm S.E.M. Statistical analysis was performed using the GraphPad Prism 5 with one-way ANOVA followed by Tukey's multiple comparison test. $P<0.05$ was considered as significant.

\section{RESULTS}

DPPH free radicals were decreased by approximately $20 \%$ at $0.01 \mathrm{mg} / \mathrm{ml}$ of Corni fructus extract and about $40 \%$ at $0.1 \mathrm{mg} / \mathrm{ml}$ as compared to the control. At 1.0 $\mathrm{mg} / \mathrm{ml}$, the DPPH free radicals decreased by around $80 \%$ and this is much stronger than that of same concentration of Vitamin E (Figure 1). Degree of lipid peroxidation is used as an index for oxidative stress and analyzed by measuring thiobarbituric acid reactive substances (TBARS). Lipid peroxides are unstable and are decomposed into various kinds of compounds including carbonyl compounds. The TBARS production was significantly suppressed by the Corni fructus extract at the concentration of $0.1 \sim 1 \mathrm{mg} / \mathrm{ml}$ and its action was equal to that found in Vitamin E (Figure 2). Regarding reducing power of Corni fructus extracts, it had the reducing power of 12.8 and 29.8 fold as compared to control at 0.1 and $1 \mathrm{mg} / \mathrm{ml}$, respectively. It exerted 5.1 fold stronger reducing power at the concentration of 1 $\mathrm{mg} / \mathrm{ml}$ than that of vitamin E (Figure 3). The amount of nitric oxide production markedly increased when the raw cells were treated with lipopolysaccharide (LPS) to activate the macrophages whereas when the cells were pretreated with the Corni fructus extract, NO production was significantly decreased by 19 and $52 \%$ in response to 0.1 and $1 \mathrm{mg} / \mathrm{ml}$ extract, respectively, as compared to the control (Figure 4).

To elucidate mechanisms of antioxidant actions by the Corni fructus extract, the expression of iNOS which is a key enzyme for the generation of NO was examined by Western blot analysis using a specific iNOS antibody. When LPS was administered to the raw cells, the expression of iNOS increased significantly. On the other hand, when the cells were pretreated with the Corni fructus 


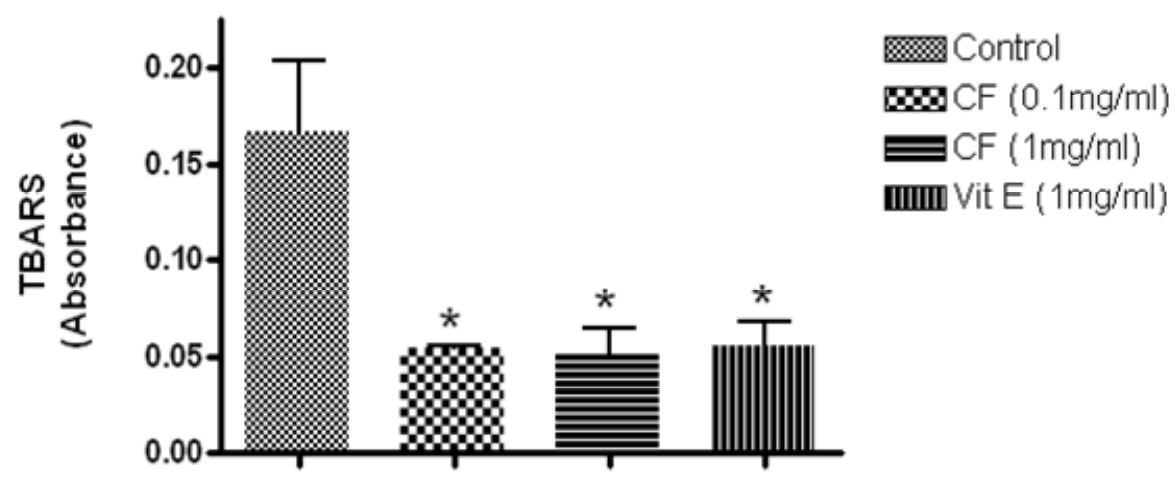

Figure 2. TBARS inhibition by Corni fructus extract. Lipid peroxidation activity of Corni fructus extracts was analyzed by measuring TBARS as described in the Methods. All the measured values were shown as means \pm S.E.M of three experiments and showed significant differences from those of the control group at the level of ${ }^{*} P<0.05$.

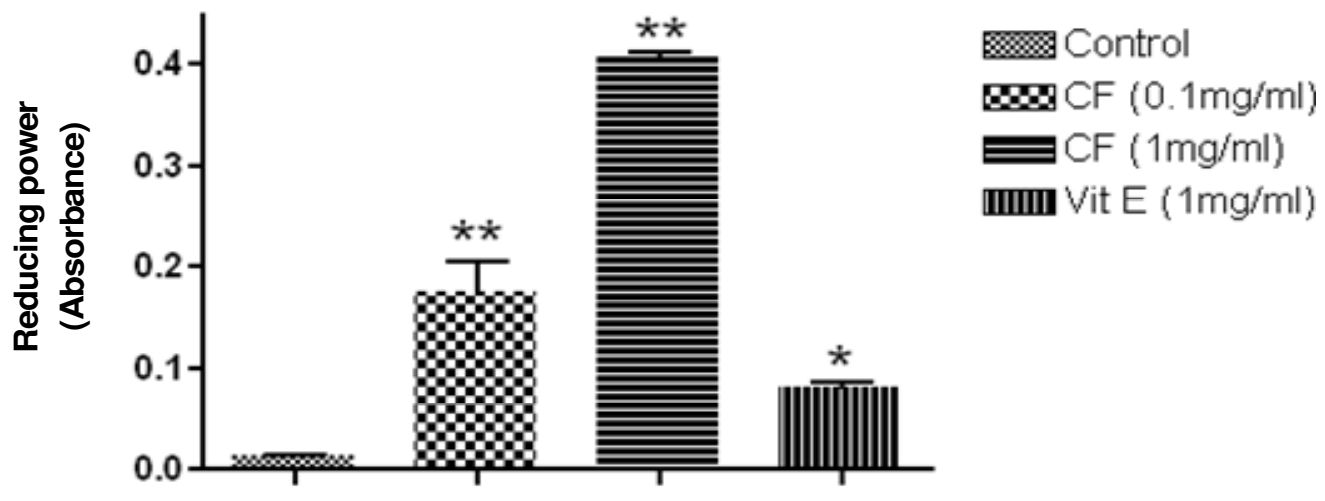

Figure 3. Reducing power by Corni fructus extract. The reducing power of Corni fructus extracts was measured as described in the methods. All the measured values were shown as means \pm S.E.M of three experiments and showed significant differences from those of the control group at the levels of ${ }^{*} \mathrm{P}<0.05,{ }^{* *} \mathrm{P}<0.01,{ }^{* *} \mathrm{P}<0.001$.

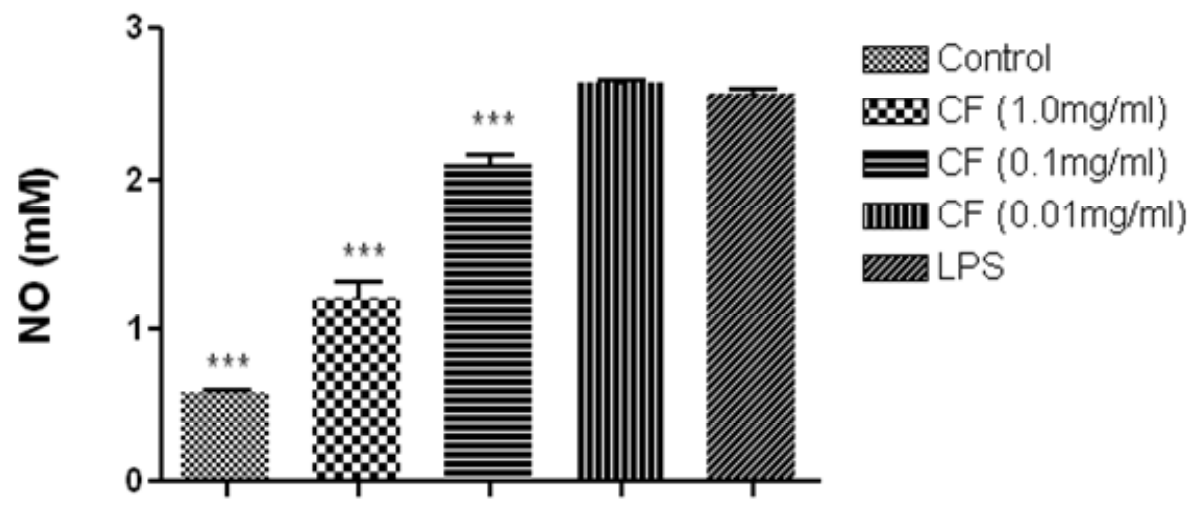

Figure 4. NO scavenging Activity by Corni fructus extract. Raw 264.7 cells were pretreated with Corni fructus extracts at the concentrations of $0.01,0.1$ and $1.0 \mathrm{mg} / \mathrm{ml}$ for four hours and then treated with LPS $10 \mathrm{mg} / \mathrm{ml}$ for 18 to $24 \mathrm{~h}$ and the amount of NO was measured using the Greiss reagent. All the measured values were shown as means \pm S.E.M of three experiments and showed significant differences from those of the LPStreated group at the levels of ${ }^{* * *} \mathrm{P}<0.001$. 
A

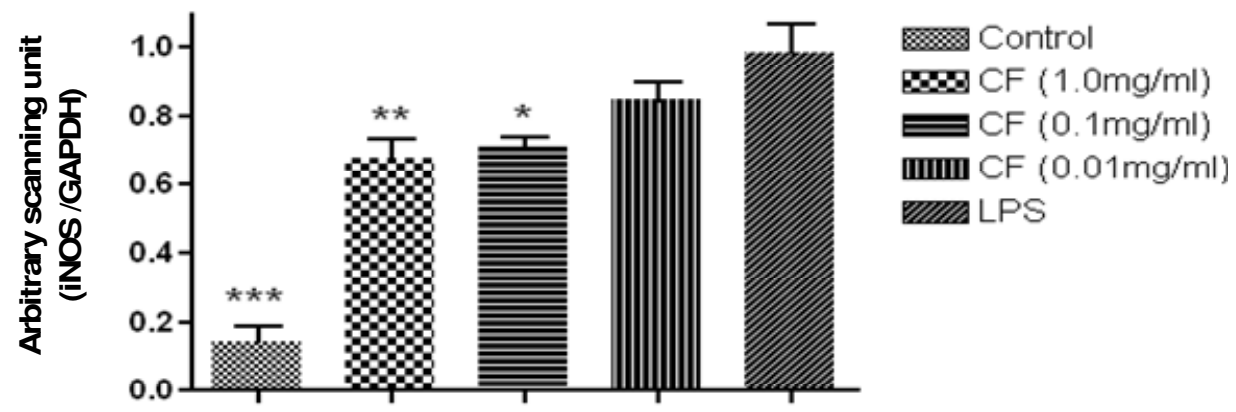

B

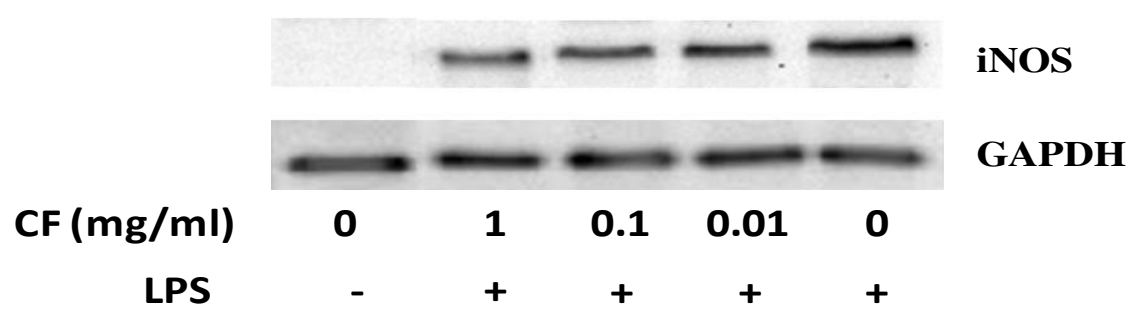

Figure 5. Effect of Corni fructus extract on LPS-induced iNOS induction. Raw 264.7 cells were pretreated with Corni fructus extracts at the concentrations of $0.01,0.1$ and $1.0 \mathrm{mg} / \mathrm{ml}$ for four hours and then treated with LPS $10 \mathrm{mg} / \mathrm{ml}$ for 18 to $24 \mathrm{~h}$ and then Western blot analysis with a specific antibody against iNOS and GAPDH as a internal control as described in the methods (B). The blots were subjected to scanning densitometry and expressed as a ratio of iNOS to GAPDH (A). All the measured values were shown as means \pm S.E.M of three experiments and showed significant differences from those of the LPS-treated group at the levels of ${ }^{*} \mathrm{P}<0.05,{ }^{* *} \mathrm{P}<0.01,{ }^{* * *} \mathrm{P}<0.001$.

extract, iNOS expression levels were markedly decreased by 14,27 , and $31 \%$ in response to $0.01,0.1$ and $1 \mathrm{mg} / \mathrm{ml}$, respectively (Figure 5). COX-2 (cyclooxygenase-2) was also explored to see if it is a target of the Corni fructus extract. When LPS was administered, the expression of the COX-2 enzyme was markedly induced; however, the Corni fructus extracts failed to inhibit the expression of LPS-induced COX-II (Figure 6).

When antioxidant components present in the $70 \%$ methanolic extract of Corni fructus $(\mathrm{T})$ were analyzed, total phenolics, total flavonoids and total anthocyanin were determined as 18.07, 2.31 and $7.83 \mathrm{mg} / \mathrm{g}$, respectively (Figure 7 ). In an effort to fractionate phenolic compound from the total extract $(T)$, subsequent extraction with chloroform under $\mathrm{pH} 3$ was performed. The chloroform fraction (C) contained total phenolics, total flavonoids and anthocyanin were determined as $7.98,6.53$ and $5.14 \mathrm{mg} / \mathrm{g}$, respectively. NO production by LPS was inhibited by 25,83 and $84 \%$ in response to 0.01 , 0.1 and $1 \mathrm{mg} / \mathrm{ml}$ the chloroform fraction $(\mathrm{C})$, respectively (Figure 8). The chloroform fraction had the ability to inhibit iNOS induction by LPS by 3, 94 and $99 \%$ in response to $0.01,0.1$ and $1 \mathrm{mg} / \mathrm{ml}$, respectively (Figure 9).

\section{DISCUSSION}

A significant body of evidence has accumulated to indicate that oxidative stress plays an important role in the development of many diseases. In the present study, we have provided evidence that Corni fructus extracts exert remarkable anti-oxidative actions possibly through iNOS inhibition, not through COX-II.

During in vivo oxygen metabolism, free radicals are unceasingly produced and take part in destroying the structure and functions of cell membranes. Accordingly, protein synthesis is interfered and mitochondrial functions are lost, eventually leading to cell damages. Oxygen free radicals are also excessively produced by various environmental factors, such as air pollution or smoking, ultraviolet rays, stress and intensive exercises and they play an essential role in damaging lipid, proteins and nucleic acid, thereby promoting various kinds of diseases and aging (Kim et al., 1997; Evereklioglu et al., 2003).

The DPPH free radical removing action of the $70 \%$ methanolic Corni extract was clearly observed in a dosedependent manner and its activity at $1 \mathrm{mg} / \mathrm{ml}$ was stronger than that of Vitamin E. Its effect on the TBARS formation was also clearly observed and it showed almost same potent as vitamin E. Moreover, the Corni 

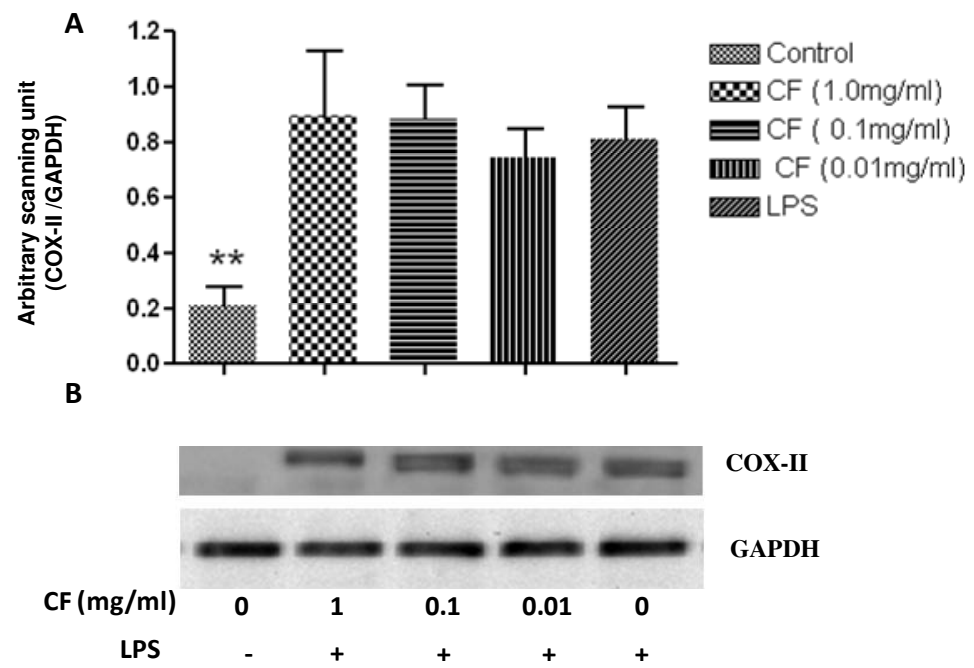

Figure 6. Effect of Corni fructus extract on LPS-induced COX-II induction. Raw 264.7 cells were pretreated with Corni fructus extracts at the concentrations of $0.01,0.1$ and $1.0 \mathrm{mg} / \mathrm{ml}$ for four hours and then treated with LPS $10 \mathrm{mg} / \mathrm{ml}$ for 18 to $24 \mathrm{~h}$ and then Western blot analysis with a specific antibody against COX-II and GAPDH as a internal control as described in the methods (B). The blots were subjected to scanning densitometry and expressed as a ratio of COX-II to GAPDH (A). The data shown are the mean values \pm SEM of three experiments and showed significant differences from those of the LPS-treated group at the levels of ${ }^{* *} P<0.01$
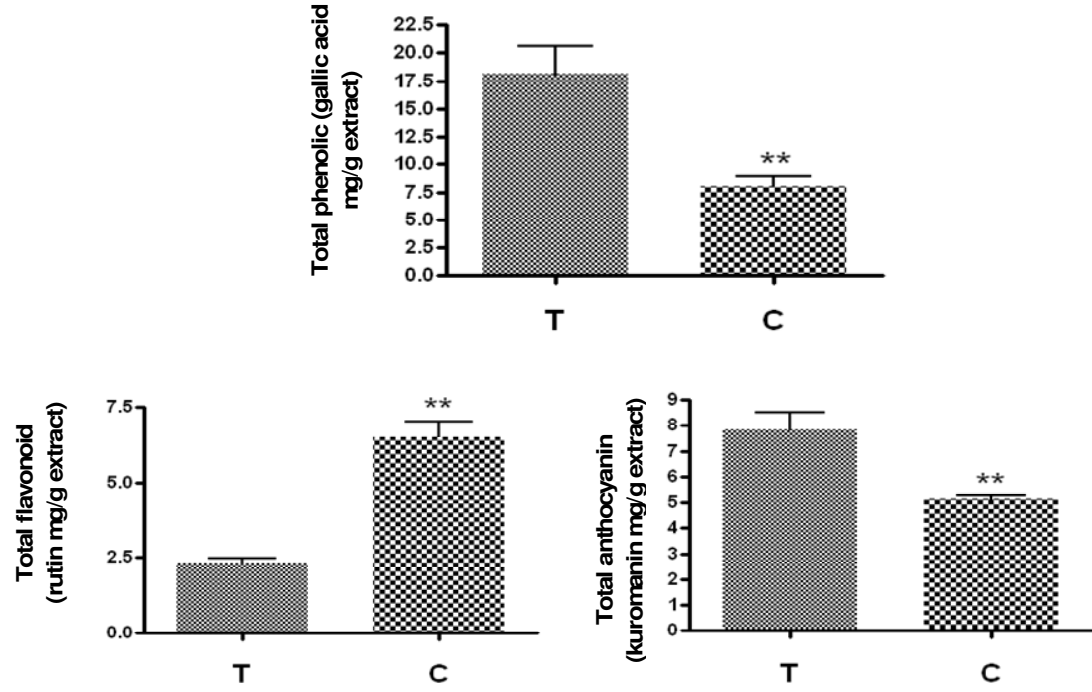

Figure 7. Antioxidant component of Corni fructus. To elucidate the antioxidant components of Corni fructus extracts, the contents of total phonolics, total flavonoids and total anthocyanin were analyzed as described in the methods. All the measured values were indicated as means \pm S.E.M of three experiments and showed significant differences from those of the control group ( $T$ ) at the levels of ${ }^{* *} \mathrm{P}<0.01$.

fructus extract has dramatic reducing power activity. Thus, it can not only remove various kinds of free radicals generated through oxidative stress but also suppress the lipid peroxidation triggered by the generation of free radicals. In addition, the marked reducing power of the extract will be beneficial in removing toxic peroxides 


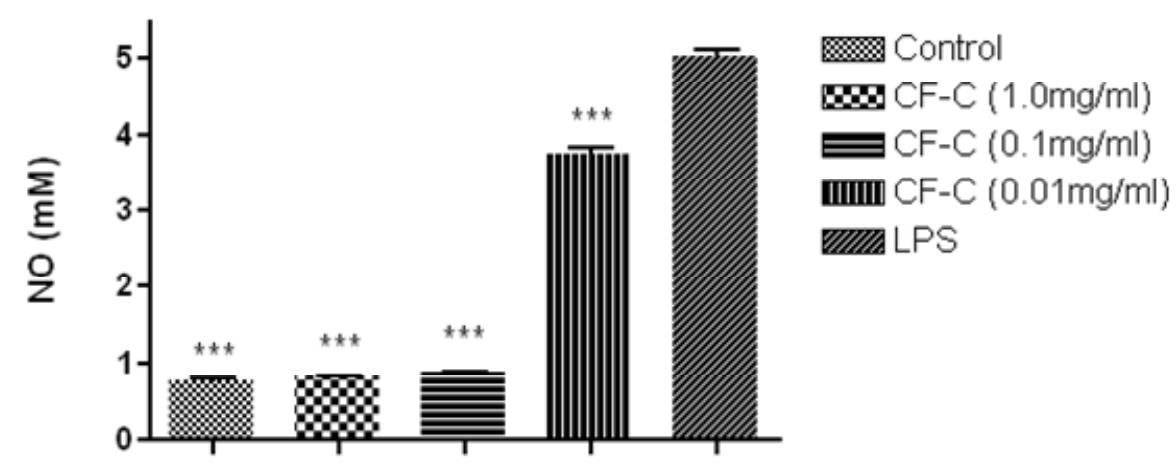

Figure 8. NO scavenging activity by chloroform fraction of Corni fructus extract. Raw 264.7 cells were pretreated with Corni fructus extracts at the concentrations of $0.01,0.1$ and $1.0 \mathrm{mg} / \mathrm{ml}$ for four hours and then treated with LPS $10 \mathrm{mg} / \mathrm{ml}$ for 18 to $24 \mathrm{~h}$ and the amount of NO was measured using the Greiss reagent. All the measured values were shown as means \pm S.E.M of three experiments and showed significant differences from those of the LPS-treated group at the levels of ${ }^{* * *} P<0.001$.

A

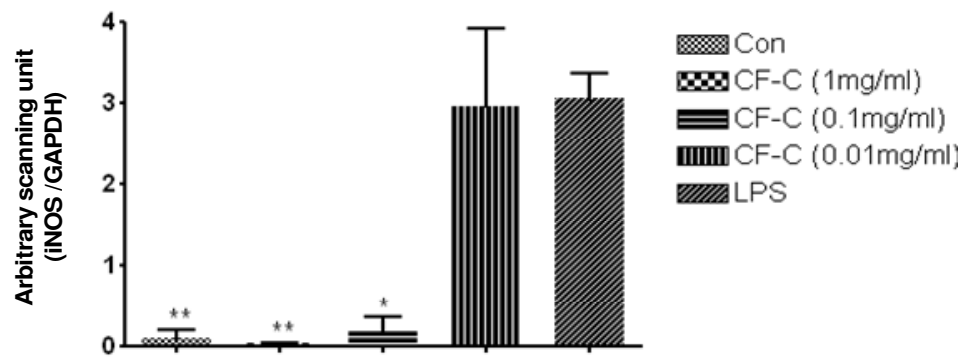

B

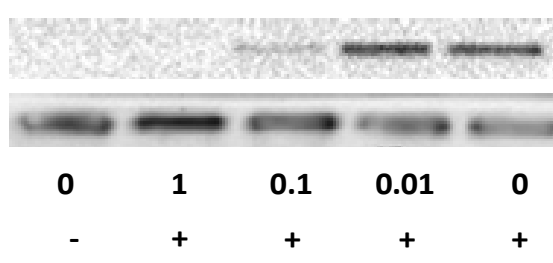

iNOS

GAPDH

$\begin{array}{cccccc}\text { CF-C Fr. }(\mathrm{mg} / \mathrm{ml}) & 0 & 1 & 0.1 & 0.01 & 0 \\ \text { LPS } & - & + & + & + & +\end{array}$

Figure 9. Effect of chloroform fraction of Corni fructus extract on LPS-induced iNOS induction. Raw 264.7 cells were pretreated with Corni fructus extracts at the concentrations of $0.01,0.1$ and $1.0 \mathrm{mg} / \mathrm{ml}$ for four hours and then treated with LPS $10 \mathrm{mg} / \mathrm{ml}$ for 18 to $24 \mathrm{~h}$ and then Western blot analysis with a specific antibody against iNOS and GAPDH as a internal control as described in the Methods (B). The blots were subjected to scanning densitometry and expressed as a ratio of iNOS to GAPDH (A). The data shown are the mean values \pm SEM of three experiments and showed significant differences from those of the LPS-treated group at the levels of ${ }^{*} \mathrm{P}<0.05,{ }^{*} \mathrm{P}<0.01$.

generated by oxidizing reactions.

Wahl et al. (2003) raised an interesting possibility to reduce pain and tissue damages by decreasing the levels of nitric oxide in the synovial fluid of patients with chronic temporomandibular diseases. It has been reported that oxidative stress could affect the progress of periodontal diseases and antioxidant substances such as flavonoids or vitamin $\mathrm{C}$ could suppress such progresses (Tomofuji et al., 2009; Sanbe et al., 2007; Canakçi, 2006). There is an interesting report showing that the degree of lipid peroxidation of cells was higher in an inflammatory disease in the oral cavity such as lichen planus than that in the mucous membranes of normal persons (AghaHosseini et al., 2009). Thus, anti-oxidants could be useful for preventing various diseases induced by oxidative stress (Linden et al., 2009). 
NO is a substance that plays an important role in various kinds of inflammatory responses in vivo and it is generated by the iNOS enzyme that is induced by inflammation. In the present study, it is identified that Corni fructus extracts significantly has the ability to reduce the content of NO generated by LPS in the raw cells with the marked inhibition of iNOS expression. On the contrary, COX-II was not affected by the treatment of Corni fructus extracts. These results suggest that the anti-oxidative action of the Corni fructus extract is mediated by the inhibition of iNOS-NO system, not through COX-II enzyme. Taken together, anti-oxidative actions of the Corni fructus extracts could be useful in the prevention and treatment of various inflammatory diseases including chronic temporomandibular diseases.

Corni fructus have diverse components including saponin, tannin, gallic acid and vitamin A. Their known pharmacological actions include the control of immunelogic functions such as suppressing the evolution of lymphoid cells and the generation of IL-2. It is also known that they have actions such as increasing white blood cell functions and suppressing various kinds of bacteria. Terpenoids and phenolics are known to be recovered in the chloroform-soluble fraction under acidic $\mathrm{pH}$ condition (Harborne, 1998). The chloroform fraction of the Corni fructus extract contains significant amount of phenolics including anthocyanins and flavonoids. Interestingly, it has been widely known that plant extract containing phenolics could exert anti-oxidant activity (Kähkönen et al., 1999). Among the phenolics, flavonoids are enriched in the chloroform fraction, suggesting that it could be a major contributor to the iNOS inhibitory action of the Corni fructus extract. In other studies, it has been found that $C$. officinalis contains morroniside, lognin, iridoid total glycoside and ursolic acid, preventing oxidative stress (Xu et al., 2006; Xu and Hao, 2004; Yu et al., 2009).

In conclusion, we propose that the antioxidant activities of the Corni fructus extract is due to the inhibition of iNOS, $\mathrm{NO}$ and free radical production. The chloroform fraction of the Corni fructus extract contains significant amount of phenolics including anthocyanins and flavonoids which might be players of the inhibiton of iNOS by the extract. This property could be applied to the prevention and treatment of various kinds of diseases triggered by oxidative stress such as temporomandibular joint diseases, periodontal diseases, ulcers, arthritis, hepatitis and nephritis. In-depth component analyses of Corni fructus extract and the identification of active principle(s) will give us insight into the development of a new therapeutics having antioxidant actions.

\section{REFERENCES}

Agha-Hosseini F, Mirzaii-Dizgah I, Mikaili S, Abdollahi M (2009). Increased salivary lipid peroxidation in human subjects with oral lichen planus. Int. J. Dent. Hyg., 22: 246-250.

Bradford MM (1976). A Rapid and Sensitive Method for the Quantitation of Microgram Quantities of Protein Utilizing the Principle of
Protein-Dye Binding. Anal. Biochem., 72: 248 - 254.

Brand-Williams W, Cuvelier ME, Berset C (1995). Use of a free radical method to evaluate antioxidant activity. Lebensm-Wiss Technol., 28: 25-30

Canakçi CF, Tatar A, Canakç IV, Cicek Y, Oztas S, Orbak R (2006). New evidence of premature oxidative DNA damage: mitochondrial DNA deletion in gingival tissue of patients with periodontitis. J. Periodontol., 77: 1894-1900.

Chang JS, Chiang LC, Hsu FF, Lin CC (2004). Chemoprevention against hepatocellular carcinoma of Cornus officinalis in vitro. Am. J. Chin. Med., 32: 717-725.

Condoner-Frnach P, Travarez-Alonso S, Murria-Estal R, Megias-Vericat $\mathrm{J}$, Tortajada-Girbes M, Alonso-Iglesias E (2011). Nitric oxide production is increased in severely obese children and related to markers of oxidative stress and inflammation. Atheroscrelosis, Epub ahead of print.

Conforti F, Menichini F (2011) Phenolic compounds from plants as nitric oxide production inhibitors. Curr. Med. Chem., 18: 1137-1145.

Ding X, Zhu FS, Yu ZL, Dong LN, Cai BC (2007). Comparative study on contents of amino acid and major and trace elements in Cornus officinalis before and after being processed. Zhong Yao Cai,, 30: 396399.

Du WF, Wang MY, Cai BC (2008). Effect of polysaccharides in crude and processed Cornus officinalis on the immunologic function of mice with immunosuppression induced. Zhong Yao Cai, 31: 715-717.

Evereklioglu C, Er H, Doganay S, Cekmen M, Turkoz Y, Otlu B, Ozerol E (2003). Nitric oxide and lipid peroxidation are increased and associated with decreased antioxidant enzyme activities in patients with age-related macular degeneration. Doc. Ophthalmol., 106: 129136.

Harborne JB (1998). Phytochemical methods. A Guide to Modern Techniques of Plants Analysis. Chapman \& Hall: London.

Hsu JH, Wu YC, Liu IM, Cheng JT (2006). Release of acetylcholine to raise insulin secretion in Wistar rats by oleanolic acid, one of the active principles contained in Cornus officinalis. Neurosci. Lett., 404: 112-116

Kähkönen MP, Hopia Al, Vuorela HJ, Rauha JP, Pihlaja K, Kujala TS, Heinonen M (1999). Antioxidant Activity of Plant Extracts Containing Phenolic Compounds. J. Agric. Food. Chem., 47: 3954-3962

Kang DG, Choi DH, Lee JK, Lee YJ, Moon MK, Yang SN, Kwon TO, Kwon JW, Kim JS, Lee HS (2007). Endothelial NO/cGMP-dependent vascular relaxation of cornuside isolated from the fruit of Cornus officinalis. Planta Med., 73: 14361440

Kim BJ, Kim JH, Kim HP, Heo MY (1997). Biological screening of 100 plant extracts for cosmetic use (II): anti-oxidative activity and free radical scavenging activity. Int. J. Cosmet. Sci., 19: 299-307.

Lee KY, Sung SH, Kim SH, Jang YP, Oh TH, Kim YC (2009). Cognitive enhancing activity of loganin isolated from Cornus officinalis in scopolamine-induced amnesic mice. Arch. Pharm. Res., 32: 677-83.

Linden GJ, McClean KM, Woodside JV, Patterson CC, Evans A, Young IS, Kee $F$ (2009). Antioxidants and periodontitis in 60-70-year-old men. J. Clin. Periodontol., 36: 843-9.

Miliauskasa G, Venskutonis PR, van Beekb TA (2004). Screening of radical scavenging activity of some medicinal and aromatic plant extracts. Food Chem., 85: 231-237.

Nawa Y, Endo J, Ohta T (2007). The inhibitory effect of the components of Cornus officinalis on melanogenesis. J. Cosmet. Sci., 58: 505-17.

Oyaizu M (1986). Studies on products of browning reaction: Antioxidative activities of products of browning reaction prepared from glucosamine. Jap. J. Nutr., 44: 307-314.

Piccolella S, Fiorentino A, Pacifico S, D'Abrosca B, Uzzo P, Monaco P (2008). Antioxidant Properties of Sour Cherries (Prunus cerasus L.): Role of Colorless Phytochemicals from the Methanolic Extract of Ripe Fruits. J. Agric. Food Chem., 56: 1928-1935

Sanbe T, Tomofuji T, Ekuni D, Azuma T, Tamaki N, Yamamoto T (2007). Oral administration of vitamin C prevents alveolar bone resorption induced by high dietary cholesterol in rats. J. Periodontol., 78: 2165-70.

Singleton VL, Rossi JA (1965). Colorimetry of total phenolics with phosphomolybdic-phosphotungstic reagents. Am. J. Enol. Vitic., 16: 144--158.

Sroka Z, Cisowski W (2003). Hydrogen peroxide scavenging, 
antioxidant and anti-radical activity of some phenolic acids. Food Chem. Toxicol., 41: 753-758.

Tomofuji T, Ekuni D, Irie K, Azuma T, Endo Y, Tamaki N, Sanbe T, Murakami J, Yamamoto T, Morita M (2009). Preventive effects of a cocoa-enriched diet on gingival oxidative stress in experimental periodontitis. J. Periodontol., 80: 1799-808.

Towbin H, Staehelin J, Gordon J (1979). Electrophoretic transfer of proteins from polyacrylamide gels to nitrocellulose sheets: procedure and some application. Proc. Natl. Acad. Sci. USA, 76: 4350-4354.

Uchida K (2008). A lipid-derived endogenous inducer of COX-2: a bridge between inflammation and oxidative stress. Mol. Cells, 25: 347-351.

Wahl SM, McCartney-Francis N, Chang J, Dionne R, Ta L, Orenstein JM (2003). Nitric Oxide in Experimental Joint Inflamation. Cells Tiss. Organs, 176: 26-33.

Wang W, Sun F, An Y, Ai H, Zhang L, Huang W, Li L (2009). Morroniside protects human neuroblastoma SH-SY5Y cells against hydrogen peroxide-induced cytotoxicity. Eur. J. Pharmacol., 613: 1923.
Xu H, Shen J, Liu H, Shi Y, Li L, Wei M (2006). Morroniside and loganin extracted from Cornus officinalis have protective effects on rat mesangial cell proliferation exposed to advanced glycation end products by preventing oxidative stress. Can. J. Physiol. Pharmacol., 84: 1267-73.

Xu HQ, Hao HP (2004). Effects of iridoid total glycoside from Cornus officinalis on prevention of glomerular overexpression of transforming growth factor beta 1 and matrixes in an experimental diabetes model. Biol. Pharm. Bull., 27: 1014-1018.

Yu HH, Hur JM, Seo SJ, Moon HD, Kim HJ, Park RK, You YO (2009). Protective effect of ursolic acid from Cornus officinalis on the hydrogen peroxide-induced damage of HEI-OC1 auditory cells. Am. J. Chin. Med., 37: 735-746.

Jang SM, ChoiJ, Kim JW, Park BY, Park BY (1996). Korean Plant Resource. Hak Mun Publishing Co., KOREA. 